\title{
THE TEMPEST: AN ECHO OF ENGLAND'S COLONIAL EXPANSION
}

\author{
Faria Saeed Khan \\ University of Balochistan, Quetta.
}

\begin{abstract}
Shakespeare's The Tempest is a social commentary on the effects of colonialism on the colonized nations. The colonized nations were forced to adopt and follow European practices. Many critics believe that The Tempest promotes condemnation of British colonial practices, seen through Prospero's abuse of power and Caliban's victimization. The Tempest has signs of condemnation for colonialism.

This research article will explore Shakespeare's handling of the issue of colonialism in The Tempest.
\end{abstract}

\section{INTRODUCTION}

'On June 2, 1609 five hundred colonists set out in nine ships from Plymouth, England, in association with the imperial Virginia Company. The aim of this expedition was to fortify John Smith's colony in Virginia. While eight of the vessels arrived at James Town, the flagship, Sea Adventure, was absent. The ship which carried the fleet's most valuable cargo, admiral Sir John Somers and the future governor of Virginia, Sir George Somers, was separated from the other eight during a fierce storm off the cost of Bermuda. William Strachey describes the tempest as 'a dread storm....which like hell of darkness turned back upon us, so much the more fuller of horror'.1

The island upon which the ship was wrecked proved a heaven for the survivors. It provided colonists with shelter, food and wood to repair the ship. The flagship arrived at James Town, a year after the Virginia Company fleet had originally sailed and this incident was regarded as a miracle. It prompted several written accounts. According to Shakespearean scholars this sensational narrative influenced Shakespeare's play The Tempest. Nearly every scene in the play portrays a relationship between a figure that possesses power and a figure that is subject to that power. The text explores the master-servant dynamic most harshly when the harmony of the relationship is threatened or disrupted by the rebellion of a servant or the ineptitude of a master. In the opening scene, the Boatswain is annoyed with the noblemen whose ineptitude threatens to lead to a shipwreck in the storm. The master-servant relationships like these dominate the play: Prospero and Caliban; Prospero and Ariel; Alonso and his nobles; the nobles and Gonzalo; Stephano, Trinculo, and Caliban; and so forth. The overriding conflict in the play is mainly between the characters of Prospero and Caliban. Through their characters Shakespeare discusses the clash between the colonizers and the colonized nations.

Prospero is a banished Duke of Milan. He is banished from his dukedom by his brother Antonio. Prospero arrives on an enchanted island with his three year old daughter Miranda. In an exposition scene he tells his daughter how he was banished by his own flesh and blood and how by some Providence Divine he got on this island. Prospero is an accomplished magus, he has special powers. Using his powers, he establishes his rule on the island. He implies that he is the legitimate ruler of the island. But the following statement makes it clear that Prospero is a usurper. Caliban's mother owned the island and that Caliban inherits it from her.

This island is mine, by Sycorax

My mother, which thou takest from me.

And here you sty me in this hard rock,

Prospero's arrival on the island and the immediate assumption of the power as well as his treatment of Caliban in teaching him his language and culture reflect his typical colonizer mentality. The storm scene with which the play begins indicates the storm within Prospero's mind. His anger at the usurpers of his dukedom seems to know no bounds. He creates terror on every side of his enemies. Gonzalo exclaims:

All torment, trouble, wonder and

Amazement inhabit here

Some heavenly power guide us

Out of this fearful country.

Prospero wants to kill his enemy to get his dukedom back. He sets up a dramatic action to torture his enemies, mentally and physically. His aim is to get back his dukedom. Some critics compare Prospero with Caliban who also wants to kill his enemy and get his island back. Prospero is a dictator who rules alone the island of illusions. Theodore Spencer believes that Prospero 'on this enchanted island is like a god, 
controlling the world of Nature and the elements.'( Theodore Spencer,1969)2. Prospero stands in contrast with King Lear, who, after facing hardships, learns the true art of majesty. He starts thinking of many and forgets "the one". He thinks it selfish to engross the luxury of the precious straw while his subjects are still in the storm. They seem to him less able than himself to resist its elemental tyranny. In one night's personal experience, King Lear is taught the sovereignty of mercy, the divine right of pity, and human kindness breathes from his lips. He says:

How shall your houseless heads and unfed sides,

Your looped and windowed raggedness

Defend you from seasons such as these?

Oh! I have taken too little care of this.

On the contrary Prospero's subjects are robbed of their will. Caliban is forced to learn the language of the colonizer. Throughout the play, Prospero seeks to impose his ideals upon his subjects and intends to eliminate by force, if necessary, all elements of humanity which will not conform to his vision.

\section{If thou neglect'st or dost unwillingly what I command, \\ I'll rack thee with old cramps. \\ Fill all thy bones with aches, \\ Make the roar that beasts shall tremble at thy din.}

The play comments on the misuses of power and depicts Prospero not as an idealized protagonist, the noble regenerator of fallen humanity, but as a colonizer. Prospero is portrayed as a usurper and a tyrant who has, made himself the ruler of the island, and its innocent natives- Caliban and Ariel his servants. Prospero requires absolute obedience from his slaves. To Ariel he says:

If thou more murmur'st I'll rend an oak

And peg thee in his knotty entrails till

Thou has howled away twelve winters.

The colonizers inhumanly punished their subjects. Physical punishments play an important part in the story of The Tempest. Prospero punishes and manipulates to stay in power. When Ferdinand shares his grief with Marinda and says, 'myself am Naples Prospero contradicts and calls him a traitor. He makes Ferdinand suffer and impose on him tasks fit for a slave. Prospero says 'he must make their courtship difficult/ Lest too light a winning/ Makes prize light.' The punishments which Ferdinand has to endure correspond exactly with that inflicted upon Caliban, who had attempted to violate Miranda's chastity. Prospero treats his slaves inhumanly. In response to Caliban's disobedience Prospero orders 'Cramps and pinches'.

For this be sure tonight thou shalt have cramps, side-stitches

That shall pen thy breath up. Urchins shall,

For the vast of night that may work, all exercise on thee.

Thou shall be pinched as thick as honeycomb,

Each pinch more stinging than bees that make them.

The spirits Prospero sends to torture Caliban are apparently animals, whose purpose is to fill Caliban's head with frightful images and sounds. Caliban says:

For every But trifle are they set upon me,

Sometimes like apes that mow and chatter at me,

And after bite me,

Then like hedgehogs, which lie tumbling in my barefoot way,

And mount their pricks at my footfall;

Sometimes am I all wound with adders,

Who with cloven tongues,

Do hiss me into madness.

Caliban warns Trinculo and Stephano about what may happen if their plot is discovered. Caliban warns that Prospero will transform them into creatures farther down on the natural scale:

We shall loose our time,

And be turned to barnacles, or to apes,

With foreheads villainous low. 
Caliban's fear of being reduced to bestiality is justified when Prospero and Ariel catch Caliban, Stephano and Trinculo. They are hunted down like animals. Prospero's attending spirits recalls the hunter's dogs chasing the rebellious slaves -

Fury, Fury; There T yrant, there,

Hark hark,

Go charge my goblins that they grind their joints

With dry culvulsions, shorten up their sinews with aged cramps,

And more pinch-spotted make them

Than pard of cat $o^{\prime}$ the mountain,

Hark, they roar

Let them be hunted soundly.

In The Tempest pain is administered to further the subjects to Prospero's rule, to ensure their cooperation and development within master and slave relationship. Prospero's frequent loss of temper shows his colonial mood. He gets annoyed when Ariel pleads for freedom and warns him:

\section{If thou more mummur'st I will rend}

An oak and peg thee in his knotty entrails.

Prospero gets hysterical when Caliban claims ownership of the island.

Thou most lying slave whom

Stripes may move, not kindness.

He feels joy at the suffering of his enemies:

At this hour lies at my mercy

All mine enemies.

Critics believe that Prospero's fits of anger reveal the ugly colonialism within. In Act five when Prospero speaks to Antonio, he makes use of the word forgiveness but does not feel the emotion and says:

For you most wicked sir,

Who to call brother would infect my mouth

I do forgive thy rankest fault, and require my

Dukedom of thee,

Which perforce I know thou must restore.

His words do not sound like forgiveness. Stephen Orgel believes that even the reconciliation and renunciation is a total sham. Prospero's change of heart occurs after his enemies are punished, after the celebration of upper class solidarity in the wedding of Ferdinand and Mirinda and after Prospero gets his empire back. He has not given up a daughter but won a throne. In returning to Milan he will reach all the goals he meant to achieve.

In The Tempest Caliban is the only native of the island. He is constantly teased about his appearance and called a beast while being enslaved. As Prospero tells us, he is the product of the witch Sycorax. Caliban was "littered" on the island after Sycorax was booted out of her home in Algiers. Prospero calls Caliban dark, earthy slave, a monster. . Caliban embodies the enslaved native. He is treated cruelly by his masters, Prospero and Stephano, his "grotesque" masters. Caliban is referred to as "monster", "a thing of darkness", "moon calf" and "poisonous slave".

Caliban stands in opposition to Prospero's authority and his teachings.Even Prospero's presence does not stop Caliban's rebellious actions, though he knows that Prospero's tortures are awaiting him. He says:

All the infections that the sun sucks up

From bogs, fens, on Prospero fall and make him

By inch meal a disease! His spirits hear me,

And yet I need must curse.

Critics are of the view that Caliban's rebellious actions emerge from his dreams of liberty, and his recollection of those days when he was free, when he was his 'own king' He plans to kill Prospero, burn his books and take over the island in-order to ensure his freedom. Prospero is the puppet master who uses his art to control Caliban's moves. Caliban says, 'I am a subject to a tyrant a sorcerer that by his cunning hath cheated me of the island'. He emphasizes that without possession of the books Prospero will be 'as I am'. 
The colonizers tried to justified their colonial oppression on the native's in-educability. Prospero, justifying, his in-human actions says:
Abhorred slave,... I pitied thee,
Took pains to make the speak, taught thee
Each hour one thing or the other; when thou
Didst not, savage know thine own meaning...
But thy vile race though thou didst learn,
Had that in it, which good natures could not abide to be with;
Therefore wast thou deservedly confined into this rock.

Caliban is a professed enemy of books. For Caliban books are the main cause of the colonial rule and the source of his punishment. He is forced to learn Prospero's language, as he is his colonial subject. The training he receives on the island is relevant to the practices of European colonists. Prospero focused on teaching Caliban a civilized tongue and language. Caliban's animosity towards education and books refer to the relationship between colonial subjects and colonizing nations. He says:

Remember first to possess his books,

For with out them he's but a sot as I am,

Nor hath not one spirit to command

They all do hate him as rootedly as I

Burn his books.

He has brave utensils, for so he calls them,

Which when he has a house he will deck withal.

For Caliban book is not source of knowledge but tools of a magician to makes possible his authority. Books are utensils, magical instruments of power and a way to authority. Critics believe that Prospero's civilizing is not enough to alter Caliban's hatred for his master. Caliban tells Stephano and Trinculo:

I am a subject to a tyrant,

A sorcerer that by his cunning

\section{Hath cheated me of the island.}

The colonists always excused their barbarity by attributing subhuman characteristics to the native population. The Europeans were of the view that other tribes were savage, pagan with no history and culture to perpetuate, that they knew nothing. The play through the character of Prospero show how the colonizers recognized the difference of the natives. Miranda makes fun of Caliban's language and says that Caliban 'gabbled like a thing most brutish.' According to Ben Ross, 'Prospero brings up the matter of the rape to divert attention from Caliban's rightful claim to the island...'4 In fact, Caliban is an innocent victim of colonial exploitation. Prospero calls him, "Abhorred slave, which any print of goodness will not take", but shares the fact with Mirinda and tells her that "we cannot miss him, he does make our fire, fetch us our woods and serve in offices that profit us".

\section{References}

[1]. Smith, Hallet. Twentieth Century Interpretations of The Tempest, USA: Engle Wood Cliff, 1969.

[2]. Brown, Joseph Russel. Shakeseare: The Tempest. Edward Arnold LTD. 1969.

[3]. Frye, Northrop. Twentieth Century Interpretations of The Tempest, USA: Engle Wood Cliff, 1969.

[4]. Spencer, Theodore. Twentieth Century Interpretations of The Tempest, USA: Engle Wood Cliff, 1969.

[5]. Durband, Alan. The Tempest, UK: The Guernsey Press, 1985.

[6]. Hibbard, G.R. The Tempest Oxford University Press, 1987.

[7]. Rickett, Compton. A History of English Literature, London: Thomas Nelson and Sons. Ltd, 1950.

[8]. Coleridge, S.T.Shakespearn Criticism: London: Aldine Press, 1974

[9]. Hibbard, G.R. King Lear : Oxford University Press, 1987.

[10]. http://shsjdyer.pbworks.com/f/Excerpt+from+William+Stracheys+Reportory.pdf 